\title{
Pengaruh Kualitas Pelayanan Terhadap Kepuasan Anggota Koperasi Kredit Bahtera Adi Guna (Bahana) Bandar Lampung
}

\author{
Theresia Yosananingtyas, Victor Marindra Ardianto* \\ STIE Gentiaras, Bandar Lampung, Lampung \\ *email:vicmansj@gmail.com
}

\begin{tabular}{|c|c|}
\hline$A R T I C L E \quad I N F O$ & $A B S T R A C T$ \\
\hline $\begin{array}{l}\text { Artikel History: } \\
\text { Received: July 16, } 2021 \\
\text { Revised: July 29, } 2021 \\
\text { Published:July 31, } 2021\end{array}$ & $\begin{array}{l}\text { This research was conducted aiming to analyze the effect of service quality on } \\
\text { member satisfaction partially. This research was conducted at the Adi Guna Bahtera } \\
\text { Credit Cooperative (Bahana) in Bandar Lampung with an exploratory research type. } \\
\text { The method of data analysis in this study uses a simple linear regression analysis } \\
\text { with a population of members of the Bahman Adi Guna Credit Cooperative } \\
\text { (Bahana) Bandar Lampung which amounted to } 125 \text { and a sample of } 100 \text { respondents } \\
\text { with a non-probability sampling technique, namely accidental sampling. Data } \\
\text { collection methods using questionnaires and interviews. Data analysis was } \\
\text { performed using the help of the SPSS program. The results showed the regression } \\
\text { equation } Y=0.833+0.958 X \text {. The service quality variable has a positive effect on } \\
\text { member satisfaction variables and is significant as evidenced by the } t \text { value of } \\
\text { 18,321 with significant value of } 0,000 \text {. Based on the output of the summary model, } \\
\text { the size of the } R \text { Square number is } 0.774, \text { which is } 77.4 \% \text {, which means that service } \\
\text { quality contributes to the satisfaction of the members of the Bandar Lampung Adi } \\
\text { Guna Credit Cooperative (Bahana) by } 77.4 \% \text {. While the remaining } 22.6 \% \text { is } \\
\text { influenced by other factors outside this factor model. }\end{array}$ \\
\hline I N F O A R T I K E L & A B S T R A K \\
\hline $\begin{array}{l}\text { Riwayat Artikel: } \\
\text { Diterima: } 16 \text { Juli } 2021 \\
\text { Direvisi: } 29 \text { Juli } 2021 \\
\text { Dipublikasikan: } 31 \text { Juli } 2021 \\
\text { Kata kunci: } \\
\text { Kualitas Pelayanan, Kepuasan }\end{array}$ & $\begin{array}{l}\text { Penelitian ini bertujuan untuk menganalisis pengaruh dari kualitas pelayanan } \\
\text { terhadap kepuasan anggota secara parsial. Penelitian ini dilakukan pada Koperasi } \\
\text { Kredit Bahtera Adi Guna (Bahana) Bandar Lampung dengan jenis penelitian } \\
\text { eksproratif. Metode analisis data dalam penelitian ini menggunakan analisis regresi } \\
\text { linier sederhana dengan populasi anggota Koperasi Kredit Bahtera Adi Guna } \\
\text { (Bahana) Bandar lampung yang berjumlah } 125 \text { dan sampel yang berjumlah } 100 \\
\text { responden dengan teknik non-probability sampling yaitu accidental sampling. } \\
\text { Metode pengumpulan data mengunakan kuesioner dan wawancara. Analisis data } \\
\text { dilakukan menggunakan bantuan program SPSS. Hasil penelitian menunjukkan } \\
\text { persamaan regresi Y }=0,833+0,958 X \text {. Variabel kualitas pelayanan berpengaruh } \\
\text { positif terhadap variabel kepuasan anggota dan signifikan dibuktikan dengan nilai t } \\
\text { sebesar } 18,321 \text { yang lebih besar dari t tabel dengan nilai signifikan sebesar } 0,000 \text {. } \\
\text { Berdasarkan hasil output model summary besarnya angka R Square adalah } 0,774 \\
\text { sama dengan } 77,4 \% \text { yang artinya bahwa kualitas pelayanan memberikan sumbangan } \\
\text { terhadap kepuasan pada anggota Koperasi Kredit Bahtera Adi Guna (Bahana) } \\
\text { Bandar Lampung sebesar } 77,4 \% \text {. Sedangkan sisanya } 22,6 \% \text { dipengaruhi oleh faktor } \\
\text { yang lainnya di luar model faktor ini. }\end{array}$ \\
\hline
\end{tabular}




\section{PENDAHULUAN}

Perkembangan lembaga keuangan yang ada di Indonesia saat ini memiliki dua jenis lembaga keuangan, yang pertama adalah lembaga keuangan bank dan yang kedua lembaga keuangan non bank. Pengertian dari lembaga keuangan bank itusendiri adalah lembaga yang menghimpun dana dari masyarakat dalam bentuk simpanan dan menyalurkan kembali kepada masyarakat dalam bentuk kredit maupun pembiayaan. Lembaga keuangan non bank (LKNB/Nonbank financial institution) merupakan bahan usaha yang melakukan kegiatan keuangan yang secara langsung maupun tidak langsung menghimpun dana dengan jalan mengeluarkan surat berharga kemudian menyalurkannya kepada masyarakat yang bertujuan untuk membiayai investasi perusahaan, salah satunya yaitu koperasi. Pengertian dari koperasi itu sendiri adalah sebuah organisasi ekonomi yang dimiliki dan dioperasikan oleh orang-seorang demi kepentingan bersama. Koperasi merupakan lembaga keuangan berbadan hukum yang siap melakukan serta membantu anggotanya dalam menjalankan ekonomi dengan cara melakukan simpan pinjam. Peranan koperasi di masyarakat baik di lingkungan perkotaan maupun di pedesaan turut membantu dalam peningkatan pertumbuhan perekonomian rakyat.

Semakin lama peranan koperasi semakin besar terutama dalam upaya meningkatkan produksi maupun incomemasyarakat Indonesia serta memberikan kontribusi dan nilai tambah dalam ekonomi serta pembangunan wilayah. Adapun indikator utama dalam pembangunan koperasi antara lain : anggota, lembaga, volume usaha, permodalan, kesempatan kerja, aset, pembiayaan dan pelayanan (Pariaman Sinaga, 2008). Koperasi mempunyai tujuan yaitu untuk mensejahterakan anggotanya, sedangkan operasional koperasi berkaitan dengan pelayanan jasa. Kepuasan dari anggota koperasi akan menjadi nilai tambah pada lembaga koperasi itu sendiri dalam peningkatan perputaran ekonomi dan penambahan anggota. Namun semua itu bergantung pada kualitas pelayanan yang diberikan oleh koperasi kepada anggota.

Menurut Kotler dan Amstrong dalam Rismi Somad dan Donni Juni Priansa (2014) kepuasan pelanggan merupakan tingkatan dimana anggapan kinerja (percieved performance) produk sesuai dengan harapan yang dirasakan oleh pelanggan. Apabila kinerja produk jual ternyata lebih rendah dibandingkan dengan harapan pelanggan, maka pelanggan tidak akan puas. Namun sebaliknya apabila kinerja sesuai dengan harapan atau bahkan melebihi harapan, maka pelanggan akan terpuaskan. Masalah pelayanan sebenarnya bukanlah masalah yang sulit, namun apabila hal tersebut kurang diperhatikan maka akan menimbulkan hal-hal yang rawan dikarenakan sifatnya yang sangat sensitif. Agar mampu bersaing, bertahan hidup serta berkembang terutama pada jaman 
sekarang, koperasi dituntut untuk dapat memberikan pelayanan terbaik yang dapat memenuhi kebutuhan serta keinginan para anggotanya.

Di samping meningkatkan kualitas pelayanan, perusahaan juga perlu untuk menjaga mutu produk (kualitas). Hal ini karena kualitas memiliki hubungan yang sangat erat dengan kepuasan pelanggan. Kualitas pelayanan akan memberikan suatu dorongan kepada pelanggan untuk menjalin hubungan yang kuat dengan perusahaan. Dalam jangka panjang ikatan seperti ini akan sangat memungkinkan bagi perusahaan untuk lebih memahami dengan seksama harapan-harapan pelanggan serta kebutuhan dari pelanggan. Dengan demikian perusahaan dapat meningkatkan kepuasan pelanggan dengan menyenangkan dan meminimumkan pengalaman pelanggan yang kurang menyenangkan.

Di dalam dunia bisnis pelanggan/anggota merupakan aset yang sangat berharga, karena pelanggan/anggota adalah faktor utama dalam agar organisasi atau bisnis tersebut dapat berjalan dengan baik. Kepuasan dari anggota dapat dilihat dari seberapa loyalitas anggota tersebut kepada sebuah organisasi atau perusahaan, karena semakin perusahaan memberikan pelayanan yanglebih terhadap anggota maka akan semakin dekat pula anggota dengan perusahaan, hal ini pula yang diutamakan oleh Koperasi Kredit Bahtera Adi Guna (Bahana) yaitu kepuasan anggota, dari anggota dan untuk anggota.

Koperasi Kredit Bahtera Adi Guna (Bahana) merupakan salah satu koperasi kredit yang berada di Kota Bandar Lampung yang menawarkan pelayanan yang ramah serta cepat tentunya. Namun dalam melakukan pelayanan masih belum maksimaldikarenakan jumlah karyawan yang terbilang sedikit, sehingga membuat pelayanan kurang maksimal. Berdasarkan uraian tersebut maka penulis tertarik untuk melakukan penelitian mengenai : "Pengaruh Pelayanan Terhadap Kepuasan Anggota Pada Koperasi Kredit Bahtera Adi Guna (Bahana) Bandar Lampung”

\section{METODE PENELITIAN}

\section{Desain Penelitian}

Metode penelitian menurut Sugiyono (2005) adalah suatu cara ilmiah untuk mendapatkan data dengan tujuan tertentu. Desain penelitian yang digunakan oleh penulis dalam penelitian ini adalah jenis penelitian deskriptif kuantitatif . Pengertian dari jenis penelitian deskriptif kuantitatif sendiri menurut Sugiyono (2005) adalah suatu metode yang digunakan untuk menggambarkan atau menganalisis suatu hasil penelitian tetapi tidak digunakan untuk membuat kesimpulan yang lebih luas. Penelitian ini dilaksanakan di Koperasi Kredit Bahtera Adi Guna (Bahana) Bandar Lampung 
yang beralamat di J1. Urip Sumoharjo, No. 39, Kedaton, Bandar Lampung. Waktu penelitian ini berlangsung selama 3 bulan, mulai dari bulan April sampai Juni 2020.

\section{Populasi dan Sampel}

Menurut Etta Mamang Sangadji dan Sopiah (2010) populasi adalah wilayah generalisasi yang terdiri atas: subjek atau objek dengan kualitas dan karakteristik tertentu yang ditetapkan oleh peneliti untuk dipelajari lalu kemudian ditarik kesimpulan. Populasi dalam penelitian ini adalah anggota Koperasi Kredit Bahtera Adi Guna (Bahana) Kota Bandar Lampung yang berjumlah 125 orang. Sedangkan, sampel (Sugiyono, 2013) adalah bagian dari jumlah karakteristik yang dimiliki oleh populasi tersebut. Peneliti mengambil sampel anggota Koperasi Kredit Bahtera Adi Guna (Bahana) Kota Bandar Lampung sebagai responden. Karena banyaknya populasi maka penentuan sampel yang dilakukan dengan cara non probability sampling dan menggunakan teknik accidental sampling yaitu penentuan sampel berdasarkan kebetulan, yaitu siapa saja yang secara kebetulan bertemu dengan peneliti yang dapat digunakan sebagai sampel. Penentuan besar sampel menggunakan rumus Slovin dalam Sugiyono (2010), $\mathrm{n}=\frac{\mathrm{N}}{1+\mathrm{N}\left(\mathrm{d}^{2}\right)}$ dengan $\mathrm{d} \quad=$ tingkat presisi yang diinginkan: 0,05 didapatkan sampel sebanyak 100 orang. Namun karena keadaan pandemi Covid-19, dari 100 kuesioner yang dibagikan kepada sampel hanya 60 yang kembali kepada peneliti.

\section{Variabel Penelitian}

\section{Jenis Variabel}

Penelitian ini terdiri atas 2 jenis variabel yaitu, kualitas pelayanan yang merupakan variabel independen (X) dan kepuasan pelanggan yang merupakan variabel dependen (Y). Variabel independen merupakan variabel yang mempengaruhi atau yang menjadi sebab perubahan pada variabel dependen. Variabel dependen merupakan variabel yang dipengaruhi atau menjadi akibat dari adanya variabel independen (Sugiyono: 2010).

\section{Definisi Operasional Variabel}

Indikator yang digunakan untuk mengukur kualitas pelayanan menurut teori Kotler(2010) yang terdiri dari berwujud (tangible), empati (empathy), keandalan (reliability), daya tanggap (responsiveness), dan kepastian atau jaminan (assurance). Sedangkan untuk variabel kepuasan pelanggan menggunakan indikator berdasarkan teori Tjiptono (2009) yang terdiri dari membeli jasa 
secara rutin, merekomendasikan kepada orang lain dan tidak terpengaruh daya tarik pelanggan pesaing. Selanjutnya akan dijelaskan pada Tabel 1 berikut:

Tabel 1. Definisi Operasional Variabel

\begin{tabular}{|c|c|}
\hline Variabel & 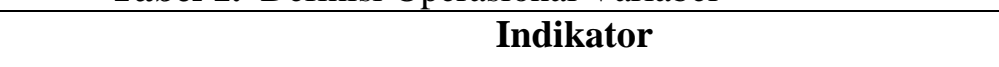 \\
\hline $\begin{array}{l}\text { Kualitas } \\
\text { pelayanan }(\mathrm{X})\end{array}$ & $\begin{array}{l}\text { Tangible } \\
\text { - } \text { Penampilan karyawan } \\
\text { - } \text { Fasilitas ruangan } \\
\text { - Tingkat kebersihan ruangan } \\
\text { - Teknologi dan peralatan yang mendukung } \\
\text { - Kempathy } \\
\text { - Kemampuan mengatasi masalah anggota } \\
\text { - Kesungguhan karyawan dalam melayani anggota } \\
\text { Reliability } \\
\text { - Pelayanan yang tepat waktu } \\
\text { - Akurasi penanganan sesuai dengan janji yang diberikan } \\
\text { - Kesamaan pelayanan terhadap semua anggota } \\
\text { Responsiveness } \\
\text { - Tanggapan segera terhadap keluhan anggota } \\
\text { - } \text { Bersikap informatif } \\
\text { - Merespon permintaan anggota dengan cepat } \\
\text { Assurance } \\
\text { - Kemampuan komunikasi karyawan } \\
\text { - Kesabaran dan keramahan karyawan } \\
\text { - }\end{array}$ \\
\hline $\begin{array}{l}\text { Kepuasan } \\
\text { Pelanggan (Y) }\end{array}$ & $\begin{array}{l}\text { Membeli jasa secara rutin } \\
\text { Merekomendasikan kepada orang lain } \\
\text { Tidak terpengaruh daya tarik pelanggan pesaing. }\end{array}$ \\
\hline
\end{tabular}

Sumber : Kotler (2010) dan Tjiptono (2009)

\section{Teknik Pengumpulan Data}

Penggolongan data yang digunakan dalam penelitian ini berupa data primer dan data sekunder yaitu: 


\section{Data primer}

Data primer merupakan data yang diperoleh secara langsung dari objek yang diteliti (responden) dan untuk kepentingan studi yang bersangkutan. Data primer dapat diperoleh dengan cara: Angket atau kuesioner, dan Wawancara tertutup (interview), yaitu dengan mengajukan pertanyaan secara langsung dan melalui sambungan telepon dengan pihak anggota Koperasi Bahtera Adi Guna (Bahana) Bandar Lampung. 


\section{Data Sekunder}

Data sekunder merupakan data yang diperoleh dengan mengumpulkan data-data dari bukubuku ilmiah serta literatur-literatur yang mempunyai hubungan dengan masalah yang dibahas dalam penelitian ini. Penulis menggunakan berbagai metode pengumpulan data yaitu Studi kepustakaan, dan Dokumentasi.

Untuk memungkinkan anggota menjawab setiap butir pertanyaan, digunakan ukuran interval berdasarkan jenis skala likert. Skala likert digunakan untuk mengukur sikap, pendapat, dan persepsi seseorang atau kelompok orang tentang fenomena sosial. Dengan skala likert, maka variabel yang diukur dapat dijabarkan sebagi titik tolak untuk menyusun item-item instrumen yang dapat berupa pernyataan ataupun pertanyaan (Sugiyono, 2008) dengan jawaban setiap item menggunakan skala likert.

\section{Teknik Analisis Data}

Uji Validitas,

Menurut Arikunto (2010) Validitas merupakan suatu ukuran yang menunjukan tingkattingkat kevalidan atau kesalahan suau instrumen dan sejauh mana daftar pertanyaan tersebut dapat diukur.

Uji Reliabilitas

Reliabilitas adalah tingkat kepercayaan hasil suatu pengukuran yang memiliki reliabilitas tinggi yaitu pengaruh yang memberikan hasil ukur yang terpercaya. Uji reliabilitas digunakan untuk menguji keandalan butir instrumen penelitian.

Analisis Regresi Sederhana

Analisis regresi linier sederhana merupakan suatu metode analisa yangdigunakan untuk menentukan ketetapan prediksi dari pengaruh yang terjadi antaravariabel independen (X) yaitu Kualitas Pelayanan terhadap variabel dependen (Y)yaitu Kepuasan Pelanggan.

Uji Normalitas

Uji normalitas bertujuan untuk menguji apakah sampel yang digunakan mempunyai distribusi normal atau tidak. Dalam model regresi linier, asumsi ini ditunjukkan oleh nilai erroryang berdistribusi normal. Model regresi yang baik adalah model regresi yang dimiliki distribusi normal atau mendekati normal,sehingga layak dilakukan pengujian secara statistik. 
Uji T (Uji Parsial)

Uji signifikan terhadap masing-masing koefisien regresi bertujuan untuk mengetahui signifikan tidaknya pengaruh masing-masing variabel bebas $\mathrm{X}$ (kualitas pelayanan) terhadap variabel terikat Y (kepuasan pe;anggan)

\section{HASIL DAN PEMBAHASAN}

\section{Uji Persyaratan Instrumen}

\section{Uji Validitas}

Uji validitas adalah uji yang digunakan untuk mengukur valid atau tidaknya kuesioner. Uji validitas ditunjukan pada 30 responden yang dilakukan dengan menggunakan korelasi product moment. Menurut Riadi Edi (2016) validitas merupakan suatu ukuran yang menunjukkan tingkat kevalidan atau ketepatan dari suatu instrumen. Pengujian instrumen dalam penelitian ini menggunakan SPSS Statistic-24. Hasil pengolahan data menggunakan SPSS Statistic-24 diperoleh hasil sebagai berikut:

Tabel 2. Hasil Uji Validitas Variabel Kualitas Pelayanan (X)

\begin{tabular}{lllll}
\hline No. Item & R hitung & \multicolumn{1}{c}{$\mathbf{R}$ Tabel } & \multicolumn{1}{c}{ Kondisi } & Keterangan \\
\hline 1 & 0,400 & 0,3494 & $\mathrm{R}_{\text {hitung }}>\mathrm{R}_{\text {tabel }}$ & Valid \\
2 & 0,477 & 0,3494 & $\mathrm{R}_{\text {hitung }}>\mathrm{R}_{\text {tabel }}$ & Valid \\
3 & 0,442 & 0,3494 & $\mathrm{R}_{\text {hitung }}>\mathrm{R}_{\text {tabel }}$ & Valid \\
4 & 0,604 & 0,3494 & $\mathrm{R}_{\text {hitung }}>\mathrm{R}_{\text {tabel }}$ & Valid \\
5 & 0,625 & 0,3494 & $\mathrm{R}_{\text {hitung }}>\mathrm{R}_{\text {tabel }}$ & Valid \\
6 & 0,487 & 0,3494 & $\mathrm{R}_{\text {hitung }}>\mathrm{R}_{\text {tabel }}$ & Valid \\
7 & 0,372 & 0,3494 & $\mathrm{R}_{\text {hitung }}>\mathrm{R}_{\text {tabel }}$ & Valid \\
8 & 0,425 & 0,3494 & $\mathrm{R}_{\text {hitung }}>\mathrm{R}_{\text {tabel }}$ & Valid \\
9 & 0,263 & 0,3493 & $\mathrm{R}_{\text {hitung }}<\mathrm{R}_{\text {tabel }}$ & Tidak Valid \\
10 & 0,222 & 0,3493 & $\mathrm{R}_{\text {hitung }}<\mathrm{R}_{\text {tabel }}$ & Tidak Valid \\
11 & 0,342 & 0,3494 & $\mathrm{R}_{\text {hitung }}<\mathrm{R}_{\text {tabel }}$ & Tidak Valid \\
12 & 0,647 & 0,3494 & $\mathrm{R}_{\text {hitung }}>\mathrm{R}_{\text {tabel }}$ & Valid \\
13 & 0,635 & 0,3494 & $\mathrm{R}_{\text {hitung }}>\mathrm{R}_{\text {tabel }}$ & Valid \\
14 & 0,444 & 0,3494 & $\mathrm{R}_{\text {hitung }}>\mathrm{R}_{\text {tabel }}$ & Valid \\
15 & 0,524 & 0,3494 & $\mathrm{R}_{\text {hitung }}>\mathrm{R}_{\text {tabel }}$ & Valid \\
16 & 0,567 & 0,3494 & $\mathrm{R}_{\text {hitung }}>\mathrm{R}_{\text {tabel }}$ & Valid \\
17 & 0,627 & 0,3494 & $\mid \mathrm{R}_{\text {hitung }}>\mathrm{R}_{\text {tabel }}$ & Valid \\
\hline
\end{tabular}

Sumber data : Diolah peneliti tahun 2020 
Tabel 2 menunjukkan bahwa hasil pengujian terhadap instrumen variabel kualitas pelayanan (X) dengan jumlah pernyataan 17 ternyata tidak seluruhnya valid. Dapat dilihat dari hasil perhitungan uji validitas di atas bahwa untuk butir pernyataan nomor 9,10 dan 11 tidaklah valid, hal ini dapat dilihat dari $\mathrm{R}$ hitung yang ternyata lebih kecil daripada $\mathrm{R}$ tabel. Hasil pengujian validitas dengan nilai terbesar adalah 0,647 , dan untuk hasil pengujian validitas dengan nilai terendah adalah 0,222. Untuk hasil olahan secara lengkap dapat dilihat pada lampiran.

Tabel 3. Hasil Uji Validitas Variabel Kepuasan Pelanggan (Y)

\begin{tabular}{lllll}
\hline No Item & \multicolumn{1}{c}{ R Hitung } & R Tabel & \multicolumn{1}{c}{ Kondisi } & Keterangan \\
\hline 1 & 0,652 & 0,3494 & $\mathrm{R}_{\text {hitung }}>\mathrm{R}_{\text {tabel }}$ & Valid \\
2 & 0,702 & 0,3494 & $\mathrm{R}_{\text {hitung }}>\mathrm{R}_{\text {tabel }}$ & Valid \\
3 & 0,633 & 0,3494 & $\mathrm{R}_{\text {hitung }}>\mathrm{R}_{\text {tabel }}$ & Valid \\
\hline
\end{tabular}

Sumber data : Diolah peneliti tahun 2020

Tabel 3 menunjukkan bahwa hasil pengujian terhadap instrumen kepuasan pelanggan (Y) dengan jumlah pernyataan 3 seluruhnya valid, dengan nilai koefisien korelasi produk momen terbesar 0,702 dan nilai koefisien korelasi produk momen terendah 0,633. Hasil olahan secara lengkap dapat dilihat pada lampiran.

\section{Uji Reliabilitas}

Reliabilitas adalah tingkat kepercayaan hasil suatu pengukuran yang memiliki reliabilitas tinggi yaitu pengaruh yang memberikan hasil ukur yang terpercaya. Uji reliabilitas digunakan untuk menguji keandalan butir instrumen penelitian. Suatu kuesioner dinyatakan reliabel atau handal apabila jawaban seseorang terhadap pertanyaan adalah konsisten dari waktu ke waktu(Ghozali, 2011). Suatu kuesioner dikatakan reliabel apabila jawaban dari kuesioner tersebut konsisten meskipun digunakan berulangkali dengan asumsi kondisi pada saat pengukuran tidak berubah. Uji reliabilitasyang dilakukan dengan menggunakan 30 sampel.Pengujian reliabilitas dalam penelitian ini menggunakan SPSS Statistic-24, yang akan memberikan bantuan untuk mengukur reliabilitas dengan uji statistik Cronbach Alpha $(\alpha)$.

Tabel 4. Hasil Uji Reliabilitas

\begin{tabular}{llll}
\hline \multicolumn{1}{c}{ Variabel } & \multicolumn{1}{c}{ R Hitung } & \multicolumn{1}{c}{ R Tabel } & Keterangan \\
\hline Kualitas Pelayanan & 0,779 & 0,3494 & Reliabel \\
Kepuasan Pelanggan & 0,355 & 0,3494 & Reliabel
\end{tabular}

Sumber Data: Diolah peneliti tahun 2020

Tabel 4 menunjukkan besar Cronbach Alpha pada variabel kualitas pelayanan (X) yaitu 0,779 yang artinya apabila kuesioner disebarkan lagi kemungkinan responden menanggapi 
pernyataan dengan jawaban yang sama sebesar 0,779 atau 77,9\%. Kemudian besar Cronbach Alpha pada variabel kepuasan pelanggan (Y) yaitu 0,355 yang artinya apabila kuesioner disebarkan lagi kemungkinan responden menanggapi pernyataan dengan jawaban yang sama sebesar 0,355 atau $35.5 \%$.

\section{Hasil Analisis Deskriptif}

Berikut ini adalah hasil tanggapan dari responden terhadap variabel kualitas pelayanan $(\mathrm{X})$ dan variabel kepuasan pelanggan (Y).

Tabel 5. Hasil Tanggapan Responden Terhadap Variabel Kualitas Pelayanan (X)

\begin{tabular}{ll}
\hline \multicolumn{1}{c}{ Pernyataan } & Total Jawaban \\
\hline Karyawan selalu tampil rapih dan bersih dalam bekerja & 224 \\
$\begin{array}{l}\text { Koperasi Bahtera Adi Guna memiliki fasilitas yang lengkap } \\
\text { Koperasi Bahtera Adi Guna memiliki ruangan yang bersih dan }\end{array}$ & 202 \\
nyaman & 222 \\
$\begin{array}{l}\text { Koperasi Bahtera Adi Guna memiliki tekonologi serta peralatan } \\
\text { yang mendukung }\end{array}$ & 214 \\
$\begin{array}{l}\text { Karyawan dapat memahami masalah yang dialami oleh anggota } \\
\text { Karyawan dapat menangani masalah atau keluhan yang dialami } \\
\text { oleh anggota secara tepat }\end{array}$ & 217 \\
$\begin{array}{l}\text { Koperasi Kredit Bahtera Adi Guna memiliki karyawan yang } \\
\text { bersungguh-sungguh dalam melayani konsumen }\end{array}$ & 208 \\
$\begin{array}{l}\text { Pelayanan yang diberikan oleh Koperasi Kredit Bahtera Adi Guna } \\
\text { tepat waktu }\end{array}$ & 202 \\
$\begin{array}{l}\text { Karyawan cepat tanggap terhadap keluhan anggota } \\
\text { Karyawan memberikan informasi yang jelas kepada calon anggota } \\
\text { dan anggota }\end{array}$ & 199 \\
$\begin{array}{l}\text { Karyawan melayani serta merespon anggota dengan cepat } \\
\text { Karyawan mampu berkomunikasi dengan baik }\end{array}$ & 196 \\
$\begin{array}{l}\text { Karyawan melayani dengan sabar dan ramah } \\
\text { Karyawan memiliki pengetahuan tentang produk dari Koperasi } \\
\text { Kredit Bahtera Adi Guna }\end{array}$ & 198 \\
\hline $\begin{array}{l}\text { Sumber Data: Diolah penelit } \\
\text { Kahy }\end{array}$ & 202 \\
\hline
\end{tabular}

Sumber Data: Diolah peneliti tahun 2020

Tabel 5 dapat ditarik kesimpulan yaitu, butir pernyataan yang mendapatkan nilai terbesar adalah butir pernyataan pertama yang berbunyi "Karyawan selalu tampil rapih dan bersih dalam bekerja", maka dari itu karyawan perlu untuk mempertahankan kerapihan dan kebersihan selama melayani anggota Koperasi Kredit Bahtera Adi Guna (Bahana) Bandar Lampung. Dan butir 
pernyataan yang mendapatkan nilai terkecil adalah butir pernyataan keenam yang berbunyi "Karyawan memiliki pengetahuan tentang produk dari Koperasi Kredit Bahtera Adi Guna”, maka dari itu perlu adanya dilakukan pelatihan untuk karyawan agar karyawan lebih paham mengenai produk-produk yang ada di Koperasi Kredit sehingga dapat menjelaskan kepada anggota secara jelas. Hal ini perlu dilakukan agar anggota lebih merasa puas dan nyaman dengan kualitas pelayanan dari Koperasi Kredit Bahtera Adi Guna (Bahana) Bandar Lampung.

Tabel 6. Hasil Tanggapan Responden Terhadap Variabel Kepuasan Anggota (Y)

\begin{tabular}{ll}
\hline \multicolumn{1}{c}{ Pernyataan } & Total Jawaban \\
\hline $\begin{array}{l}\text { Saya akan membeli jasa menabung dan meminjam yang ada di } \\
\text { Koperasi Kredit Bahtera Adi Guna secara rutin }\end{array}$ & 248 \\
$\begin{array}{l}\text { Saya akan merekomendasikan Koperasi Kredit Bahtera Adi Guna } \\
\text { kepada orang lain }\end{array}$ & 238 \\
$\begin{array}{l}\text { Saya tidak akan terpengaruh dengan promosi dari pelanggan } \\
\text { pesaing }\end{array}$ & 250 \\
\hline
\end{tabular}

Sumber Data: Diolah peneliti tahun 2020

Tabel 6 dapat ditarik kesimpulan yaitu, butir pernyataan yang mendapatkan nilai terbesar adalah butir pernyataan ketiga yang berbunyi "Saya tidak akan terpengaruh dengan promosi dari pelanggan pesaing”. Maka dari itu kualitas pelayanan dari Koperasi Kredit Bahtera Adi Guna (Bahana) Bandar Lampung perlu dipertahankan bahkan ditingkatkan. Hal ini bertujuan agar anggota tidak terpengaruh dengan promosi dari pelanggan yang menjadi pesaing bagi koperasi. Dan butir pernyataan yang mendapatkan nilai terkecil adalah butir pernyataan kedua yang berbunyi "Saya akan merekomendasikan Koperasi Kredit Bahtera Adi Guna kepada orang lain”. Hal ini menunjukkan bahwa sebagian besar anggota enggan untuk merekomendasikan Koperasi Kredit Bahtera Adi Guna (Bahana) Bandar Lampung kepada orang lain, maka dari itu koperasi perlu untuk meningkatkan pelayanan, karena apabila pelayanan yang diterima oleh anggota ternyata memuaskan maka mereka pasti tidak akan sungkan untuk merekomendasikan Koperasi Kredit Bahtera Adi Guna (Bahana) Bandar Lampung kepada orang lain.

\section{Analisis Data}

\section{Analisis Regresi Sederhana}

Analisis regresi linier sederhana merupakan suatu metode analisa yangdigunakan untuk menentukan ketetapan prediksi dari pengaruh yang terjadi antaravariabel independen (X) yaitu Kualitas Pelayanan terhadap variabel dependen (Y) yatu Kepuasan Pelanggan. Analisis regresi linier sederhana digunakan untuk mengetahui pengaruh antara variabel bebas yang merupakan 
kualitas pelayanan (X) dengan variabel terikat yang merupakan kepuasan pelanggan (Y). Analisis data dilakukan dengan menggunakan bantuan program SPSS Statistic-24.

Tabel 7. Hasil Uji Regresi Linier Sederhana

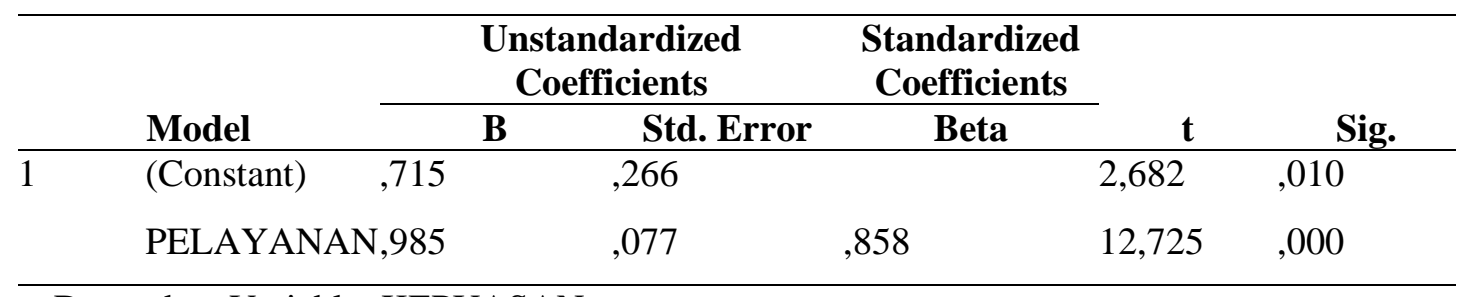

a. Dependent Variable: KEPUASAN

Tabel coefficientspada kolom B Constant (a) adalah 0,715 sedangkan Pelayanan (b) adalah 0,985 sehingga persamaan regresinya dapat ditulis sebagai berikut:

$$
\begin{aligned}
& Y=a+b X \\
& Y=0,715+0,985 X
\end{aligned}
$$

Persamaan tersebut dapat dijelaskan bahwa Konstanta (a) yaitu sebesar 0,715 yang artinya apabila variabel kualitas pelayanan dianggap nol, maka besarnya kepuasan anggota Koperasi Kredit Bahtera Adi Guna Bandar Lampung adalah positif 0,715. Selain itu, Nilai koefisien $B$ pada variabel kualitas pelayanan sebesar 0,985 yang artinya setiap peningkatan 1 nilai variabel X maka nilai kepuasan pelanggan mengingkat sebesar 0,985 dengan asumsi yang lain adalah tetap dan begitupun sebaliknya.

\section{Uji Normalitas}

Uji normalitas bertujuan untuk menguji apakah sampel yang digunakan mempunyai distribusi normal atau tidak. Dalam model regresi linier, asumsi ini ditunjukkan oleh nilai error yang berdistribusi normal. Model regresi yang baik adalah model regresi yang dimiliki distribusi normal atau mendekati normal,sehingga layak dilakukan pengujian secara statistik. Sebelum dilakukan uji hipotesis menggunakan regresi linier sederhana perlu dilakukah uji normalitas terlebih dahulu. Berikut ini hasil uji normalitas P-P plot: 


\section{Normal P-P Plot of Regression Standardized Residual}

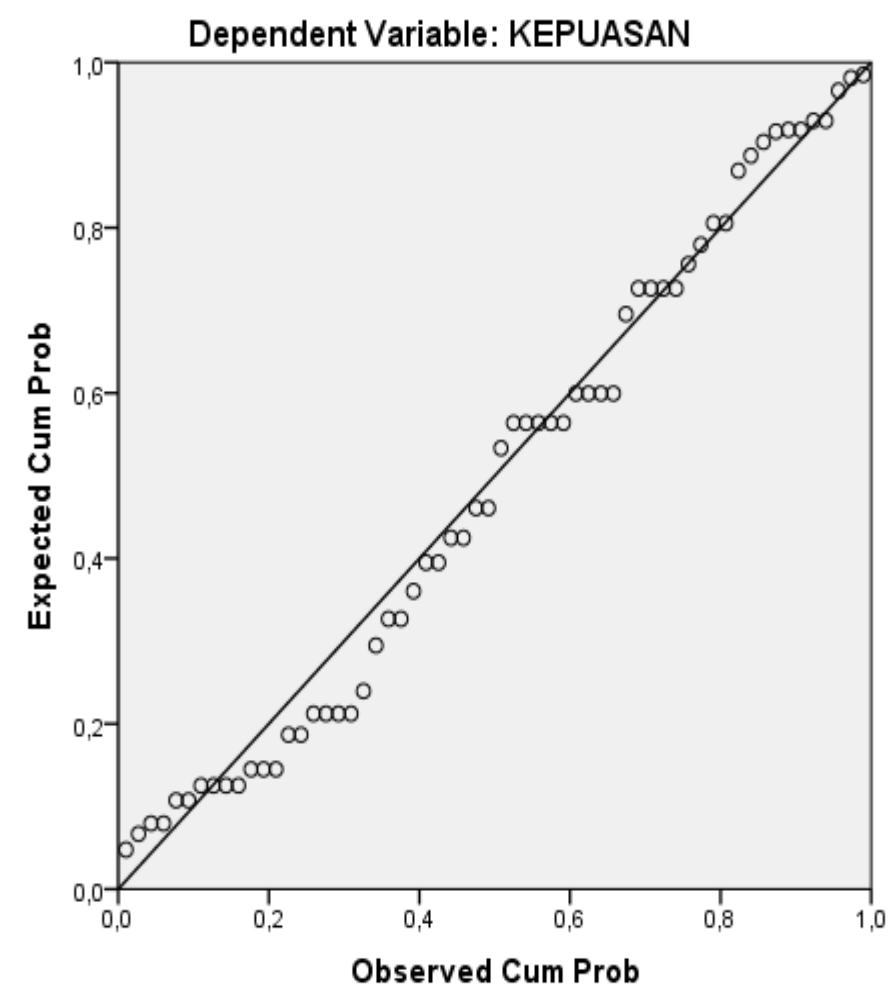

Gambar 1. Grafik Uji Normalitas

Gambar 1 di atas dan dasar pengambilan keputusan dapat disimpulkan bahwa data dalam penelitian ini berdistribusi normal. Hal ini dapat dilihat dari penyebaran titik-titik berada yang di sekitar garis diagonal dan sepanjang garis mengikuti garis diagonal.

\section{Uji Parsial (Uji T)}

Pengujian uji parsial (uji t) dilakukan terhadap koefisien regresi secara parsial, pengujian ini dilakukan untuk mengetahui peran parsial antara variabel bebas (X) dengan variabel terikat (Y).

Tabel 8. Hasil Uji Regresi Parsial (Uji T)

\begin{tabular}{|c|c|c|c|c|c|c|}
\hline & \multirow[b]{2}{*}{ Model } & \multicolumn{2}{|r|}{$\begin{array}{l}\text { Unstandardized } \\
\text { Coefficients }\end{array}$} & \multirow{2}{*}{$\begin{array}{c}\text { Standardized } \\
\text { Coefficients } \\
\text { Beta }\end{array}$} & \multirow[b]{2}{*}{$\mathbf{T}$} & \multirow[b]{2}{*}{ Sig. } \\
\hline & & & \begin{tabular}{l|l} 
B & Std. Error \\
\end{tabular} & & & \\
\hline \multirow[t]{2}{*}{1} & (Constant) & ,715 & ,266 & & 2,682 & ,010 \\
\hline & PELAYANAN & ,985 & ,077 & ,858 & 12,725 & ,000 \\
\hline
\end{tabular}

Sumber : Data diolah

Tabel 8 diketahui nilai thitung pada variabel kualitas pelayanan yaitu sebesar 12,725 dan nilai sig sebesar 0,000 . Hal tersebut menunjukkan bahwa nilai $t_{\text {hitung }}(12,725)$ lebih besar dari pada $t_{\text {tabel }}$ 
(1,) dan sig sebesar 0,000 lebih kecil daripada 0,05. Dengan demikian dapat disimpulkan bahwa Ho ditolak dan Ha diterima. Artinya variabel kualitas pelayanan mempunyai pengaruh yang signifikan terhadap kepuasan anggota Koperasi Kredit Bahtera Adi Guna (Bahana) Bandar Lampung.

\section{KESIMPULAN}

Hasil analisis data dan pengujian hipotesis tentang Kualitas Pelayanan Terhadap Kepuasan Anggota Koperasi Kredit Bahtera Adi Guna Bandar Lampung maka dapat diperoleh kesimpulan bahwa, hasil dari nilai t dengan $\alpha$ sebesar 0,05 yaitu 18,321 dan lebih besar daripada $\mathrm{t}$ tabel. Kemudian diperoleh persamaan regresi yaitu, $\mathrm{Y}=0,833+0,958 \mathrm{X}$ dimana nila pada koefisien $\mathrm{B}$ pada variabel kuliatas pelayanan yaitu sebesar 0,958 yang artinya untuk setiap peningkatan variabel $\mathrm{X}$ sebesar satu satuan maka kepuasan anggota akan meningkat sebesar 0,958. Koefisien bernilai positif hal ini berarti bahwa adanya hubungan positif antara kualitas pelayanan dengan kepuasan anggota Koperasi Kredit Bahtera Adi Guna Bandar Lampung. Maka dari itu apabila semakin tinggi kualitas pelayanan maka akan semakin tinggi pula kepuasan anggota dan begitupun sebaliknya.

Nilai dari koefisien determinasi $\mathrm{R}^{2}$ (R Square) dari output model summary adalah sebesar 0,774 atau $77,4 \%$. Hal ini bermakna bahwa persentase pengaruh kulitas pelayanan terhadap kepuasan anggota adalah sebesar 77,4\% atau dengan kata lain bahwa variabel kepuasan anggota pada Koperasi Kredit Bahtera Adiguna Bandar Lampung dipengaruhi oleh kualitas pelayanan sebesar 77,4\% sedangkan sisanya 22,6\% dipengaruhi oleh faktor lain yang tidak termasuk ke dalam penelitian ini.

Penelitian dengan topik atau bidang sejenis ini perlu dipertimbangakn bahwa peningkatan pengetahuan karyawan tentang produk melalui pelatihan. Hal tersebut perlu dilakukan agar anggota Koperasi Kredit Bahtera Adiguna Bandar Lampung merasa puas dan tetap bertahan.

\section{DAFTAR PUSTAKA}

Arikunto, Suharsimi. 2012. Prosedur Penelitian Suatu Pendekatan Praktek, Penerbit Bina Aksara: Jakarta.

As'ad, M. 2013. Psikologi Industri. Liberty: Yogyakarta.

Davis, Keith \& John W. Newstrom. 2012. Human Behavior at Work: Organizational Behavior, McGraw - Hill Education: New York.

Djoko Muljono. 2012. Buku Pintar Strategi Bisnis Koperasi Simpan Pinjam, Andi Offset: Yogyakarta.

Edwin B Flippo. 2012.Personel Management (Manajemen Personalia), Edisi. VII Jilid II. Terjemahan Alponso S. Erlangga: Jakarta 
Fandy Tjiptono. 2006. Manajemen Pemasaran, Andi: Yogyakarta.

Fandy Tjiptono.. 2009.Strategi Pemasaran, edisi kedua, cetakan ketujuh. Andi Offset: Yogyakarta.

Fandy Tjiptono.. 2011. Pemasaran Jasa, Banyumedia: Yogyakarta.

Ghozali, Imam. 2016. Aplikasi Analisis Multivariete Dengan Program (IBM SPSS,Edisi 8, Badan Penerbit Universitas Diponegoro: Semarang.

Hastono, S., \& Sabri, L. 2010. Statistik Kasehatan. PT. Raja Grafindo Persada: Jakarta.

Irawan Handi, 2006. 10 Prinsip Kepuasan Pelanggan, Elex Media Komputindo: Jakarta.

Kotler, P. 2010. Manajemen Pemasaran di Indonesia, Salemba Empat: Jakarta.

Kotler, P. . 2012. Manajemen Pemasaran terjemehan. Jilid.1. PT Prenhallindo: Jakarta.

Pariaman Sinaga, dkk. 2008. Koperasi dalam Sorotan Peneliti, Raja Grafindo Persada: Jakarta.

Riadi, Edi. 2016. Statistika Penelitian, Andi Offset: Yogyakarta.

Rismi Somad dan Donni Juni Priansa. 2014. Manajemen Komunikasi mengembangkan Bisnis Berorientasi Pelanggan, Alfabeta: Bandung.

Rudianto. 2010. Akuntansi Koperasi, Edisi kedua. Erlangga: Jakarta.

Sangadji, Etta Mamang dan Sopiah. 2010. Metodologi Penelitian, Pendekatan Praktis dalam Penelitian. Andi: Yogyakarta.

Santoso, Singgih. 2012. Statistik Parametik. PT Gramedia Pustaka Umum: Jakarta

Sugiyono. 2005. Metode Penelitian Bisnis. Alfabeta: Bandung.

Sugiyono. 2010. Metode Penelitian Kombinasi. Alfabeta: Bandung.

Sugiyono. 2013. Metode Penelitian Administrasi. Alfabeta: Bandung.

Zeithaml, V.A., M.J. Bitner, D.D. Gremler. 2013. Services Marketing: Integrating Customer Focus Across the Firm, Edisi 6. Mc.Graw-Hill: Boston. 